Prepared in cooperation with the South Carolina Department of Transportation

\title{
Evaluation of the U.S. Geological Survey Streamgage Network in South Carolina, 2017
}

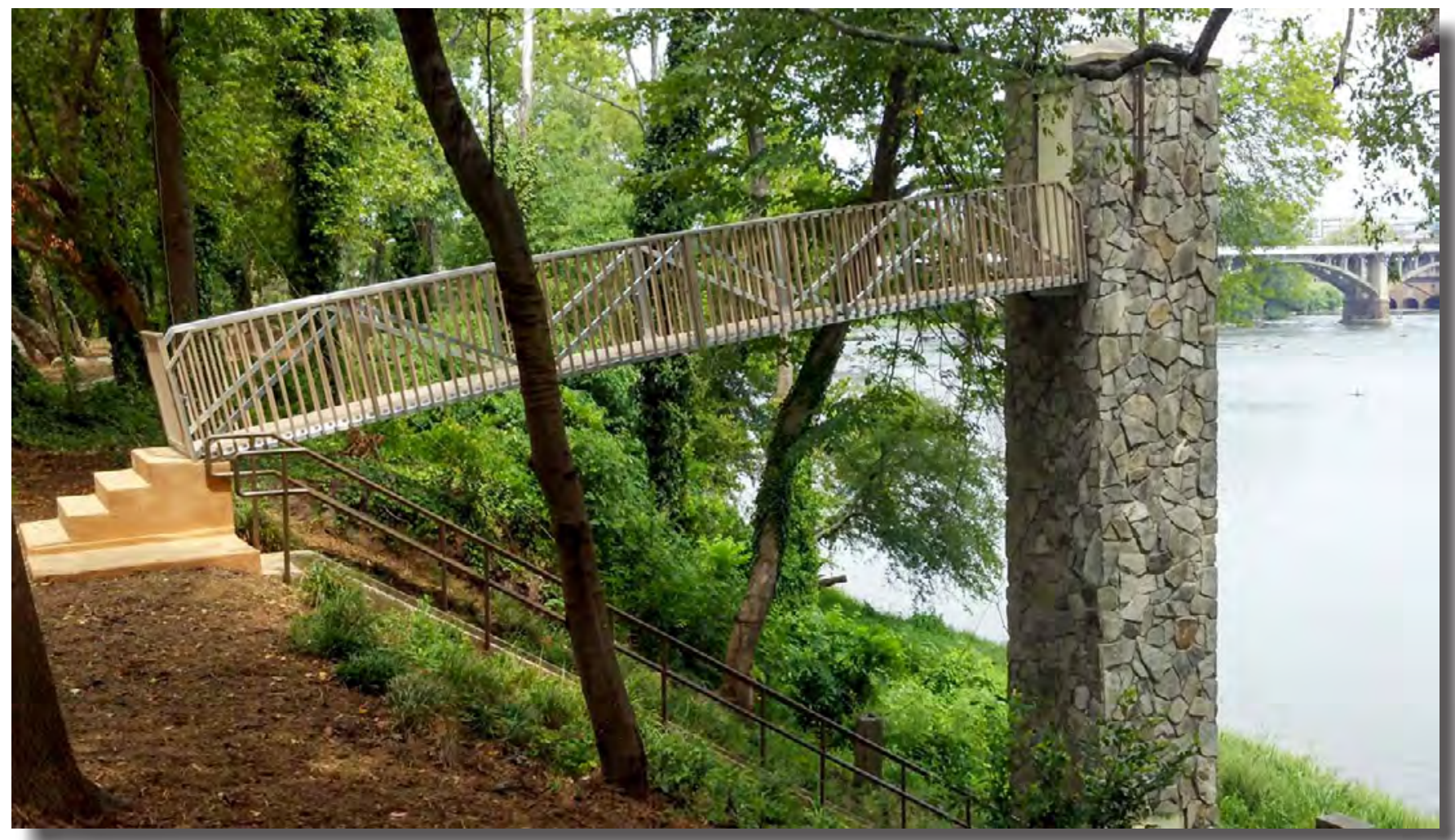

Open-File Report 2020-1104 
Cover. U.S. Geological Survey station 02169500, Congaree River at Columbia, South Carolina, July 31 , 2012. Photograph from U.S. Geological Survey. 


\section{Evaluation of the U.S. Geological Survey Streamgage Network in South Carolina, 2017}

By Toby D. Feaster and Katharine R. Kolb

Prepared in cooperation with the South Carolina Department of Transportation

Open-File Report 2020-1104 


\title{
U.S. Department of the Interior \\ DAVID BERNHARDT, Secretary
}

\author{
U.S. Geological Survey \\ James F. Reilly II, Director
}

U.S. Geological Survey, Reston, Virginia: 2020

For more information on the USGS - the Federal source for science about the Earth, its natural and living resources, natural hazards, and the environment—visit https://www.usgs.gov or call 1-888-ASK-USGS.

For an overview of USGS information products, including maps, imagery, and publications, visit https://store.usgs.gov/.

Any use of trade, firm, or product names is for descriptive purposes only and does not imply endorsement by the U.S. Government.

Although this information product, for the most part, is in the public domain, it also may contain copyrighted materials as noted in the text. Permission to reproduce copyrighted items must be secured from the copyright owner.

Suggested citation:

Feaster, T.D., and Kolb, K.R., 2020, Evaluation of the U.S. Geological Survey streamgage network in South Carolina, 2017: U.S. Geological Survey Open-File Report 2020-1104, 15 p., https://doi.org/10.3133/ofr20201104.

Associated data for this publication: Kolb, K.R., and Feaster, T.D., 2020, Data for the evaluation of the U.S. Geological Survey streamgage network in South Carolina, 2017: U.S. Geological Survey data release, https://doi.org/10.5066/P9X5F4B1.

ISSN 2331-1258 (online) 


\section{Acknowledgments}

The authors would like to acknowledge the South Carolina Department of Transportation for its long-standing cooperative partnership with the U.S. Geological Survey (USGS), which has facilitated both streamgaging and scientific investigations. We would also like to acknowledge the many other Federal, State, and local agencies who have partnered with the USGS in South Carolina since the beginning of the streamgaging program in the State. Such partners are vitally important in efforts to collect the streamflow data needed to make informed scientific decisions related to the water resources of South Carolina. The water-resources decisions being made today are strengthened by the historical streamflow records collected throughout the years that help provide a long-term perspective for researchers, engineers, and managers.

The authors would also like to acknowledge the current and former USGS hydrologic technicians who collect streamflow data throughout the year, maintain streamgages, and analyze the streamflow records to provide the data in a timely manner. 



\section{Contents}

Acknowledgments ……...................................................................................................................

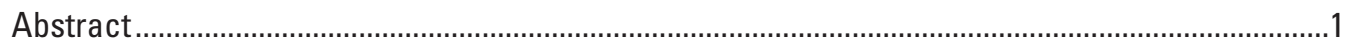

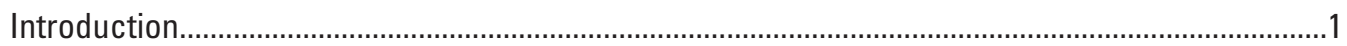

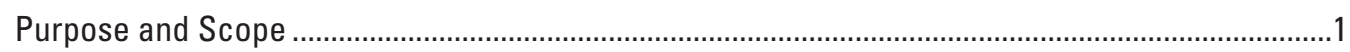

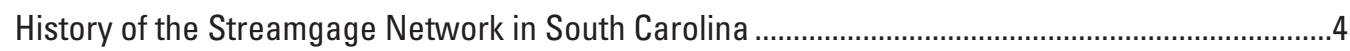

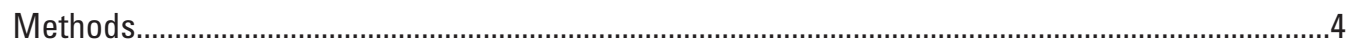

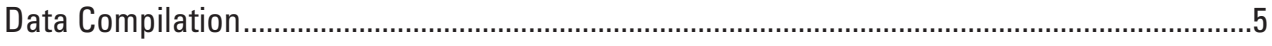

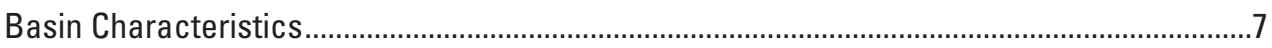

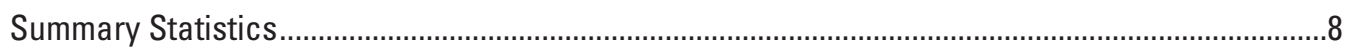

Rural Streamgages With 10 or More Years of Record............................................................

Rural Streamgages With Less Than 10 Years of Record ............................................................

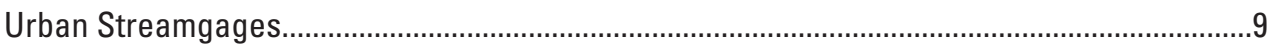

Considerations for the Selection of New Streamgage Locations ................................................10

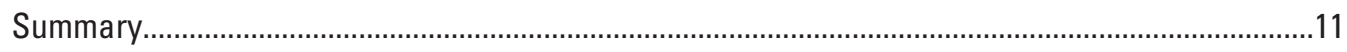

References Cited.............................................................................................................11

Appendix 1. U.S. Geological Survey Streamgages in South Carolina With Record Through September 2017—Rural Streamgages With 10 or More Years of Record............13

Appendix 2. U.S. Geological Survey Streamgages in South Carolina With Record Through September 2017—Rural Streamgages With Less Than 10 Years of Record ........14

Appendix 3. U.S. Geological Survey Streamgages in South Carolina With Record Through September 2017—Urban Streamgages With Varying Years of Record ................15

\section{Figures}

1. Map of hydrologic regions in South Carolina with the locations of streamgages

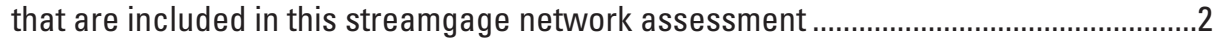

2. Map of counties and hydrologic regions in South Carolina ..............................................

3. Graph showing rating curve 4.0 at station 02172300 , McTier Creek near Moneta, South Carolina, August 17, 2007 ...................................................................................

4. Photograph of a U.S. Geological Survey hydrologic technician taking a streamflow measurement near station 02172300, McTier Creek near Monetta, South Carolina, on August 17, 2007.

5. Photographs of crest-stage gages at U.S. Geological Survey station 02185200 , Little River near Walhalla, South Carolina, on September 14, 2019 ..................................7

6. Box plot of drainage area for active and inactive rural streamgages in the U.S. Geological Survey streamgage network in South Carolina with 10 or more years of record along with the mean, median, and 90th, 75th, 25th, and 10th-percentile drainage areas.

7. Box plot of drainage area for active and inactive rural streamgages in the U.S. Geological Survey streamgage network in South Carolina with less than 10 years of record along with the mean, median, and 90th, 75th, 25th, and 10th-percentile drainage areas.

8. Box plot of drainage area for active and inactive urban streamgages in the U.S. Geological Survey streamgage network in South Carolina along with the mean, median, and 90th, 75th, 25th, and 10th-percentile drainage areas. 


\section{Table}

1. Number of active and inactive streamgages across the four hydrologic regions (HRs) in South Carolina (Piedmont, Blue Ridge, Sand Hills, and Coastal Plain) for which 75 percent or more of the corresponding drainage basin is contained within one hydrologic region

\section{Plate}

1. Map of South Carolina showing the location, station number, and type of streamgages with at least one peak-flow measurement as of

September 2017

https://doi.org/10.3133/ofr20201104

\section{Conversion Factors}

U.S. customary units to International System of Units

\begin{tabular}{|c|c|c|}
\hline Multiply & By & To obtain \\
\hline \multicolumn{3}{|c|}{ Length } \\
\hline inch (in.) & 2.54 & centimeter $(\mathrm{cm})$ \\
\hline inch (in.) & 25.4 & millimeter (mm) \\
\hline foot $(\mathrm{ft})$ & 0.3048 & meter $(\mathrm{m})$ \\
\hline mile (mi) & 1.609 & kilometer $(\mathrm{km})$ \\
\hline \multicolumn{3}{|c|}{ Area } \\
\hline square mile $\left(\mathrm{mi}^{2}\right)$ & 259.0 & hectare (ha) \\
\hline square mile $\left(\mathrm{mi}^{2}\right)$ & 2.590 & square kilometer $\left(\mathrm{km}^{2}\right)$ \\
\hline \multicolumn{3}{|c|}{ Flow rate } \\
\hline foot per second $(\mathrm{ft} / \mathrm{s})$ & 0.3048 & meter per second $(\mathrm{m} / \mathrm{s})$ \\
\hline cubic foot per second ( $\left.\mathrm{ft}^{3} / \mathrm{s}\right)$ & 0.02832 & cubic meter per second $\left(\mathrm{m}^{3} / \mathrm{s}\right)$ \\
\hline
\end{tabular}

\section{Datum}

Horizontal coordinate information is referenced to either the North American Datum of 1927 (NAD 27) or the North American Datum of 1983 (NAD 83). 


\section{Abbreviations}

$\begin{array}{ll}\text { ADAPS } & \text { Automated Data Acquisition Processing System } \\ \text { CR } & \text { continuous-record } \\ \text { CSG } & \text { crest-stage gage } \\ \text { GIS } & \text { geographic information system } \\ \text { HR } & \text { hydrologic region } \\ \text { NLCD2016 } & \text { National Land Cover Database 2016 } \\ \text { NWIS } & \text { National Water Information System } \\ \text { SCD0T } & \text { South Carolina Department of Transportation } \\ \text { USGS } & \text { U.S. Geological Survey }\end{array}$





\title{
Evaluation of the U.S. Geological Survey Streamgage Network in South Carolina, 2017
}

\author{
By Toby D. Feaster and Katharine R. Kolb
}

\begin{abstract}
The U.S. Geological Survey (USGS) has been monitoring streamflow in South Carolina since the late 1800s. From the beginning, the USGS streamgage network in South Carolina has been dynamic, with streamgages being added or removed depending on their purpose and the availability of funding from Federal, State, and local partners. Streamflow monitoring is important for acquiring real-time data during flood events, but also for collecting long-term data that can be used to compute the magnitude and frequency of floods and to frame flood events in a historical perspective. These data are also critical for being able to develop regional regression equations that can be used to estimate flood characteristics at ungaged locations, which is important for infrastructure planning and design. The historical flooding that occurred in South Carolina in 2015, 2016, and 2018 highlighted the importance of collecting these data. Therefore, the USGS, in cooperation with the South Carolina Department of Transportation, evaluated the USGS streamgage network in South Carolina for the purpose of helping guide decisions concerning future streamgage location selection, both spatially and in terms of the range of drainage basin characteristics that are typically important in flood-frequency analyses. The results of this evaluation are presented in this report.
\end{abstract}

\section{Introduction}

Hurricanes Joaquin (October 2015), Matthew (October 2016), and Florence (September 2018) resulted in devastating flooding in North and South Carolina and brought into focus the importance of streamflow monitoring (Feaster and others, 2015, 2018b; Weaver and others, 2016). One of the best ways to understand such events, in terms of magnitude and frequency of occurrence, is by analyzing data collected at long-term streamgaging stations (also referred to as streamgages, streamflow-gaging stations, gages, gaging stations, or stations). Ideally, a streamgage would be available at locations of interest and frequency statistics could then be computed directly from those streamgage records. However, with limited resources, it is not practical to have a streamgage on every stream. A network of streamgages that covers a wide range of basin characteristics and provides broad geographical coverage in the various hydrologic regions (HRs) allows for the development of regional regression equations that can be used to estimate flow statistics at ungaged locations.

Hydrologic regions are geographical areas in which flow statistics (such as flood-frequency and low-flow frequency statistics) computed for streamgages in those regions have similar response characteristics. The statistics from streamgages in those hydrologic regions can be used to develop regional regression equations to estimate the flow statistics at ungaged locations. The most recent rural and urban flood-frequency investigations for South Carolina (Feaster and others, 2009, 2014) resulted in four hydrologic regions: HR1-Piedmont, HR2-Blue Ridge, HR3-Sand Hills, and HR4-Coastal Plain (figs. 1, 2).

Recognizing the need for accurate, up-to-date streamflow data, the U.S. Geological Survey (USGS), in cooperation with the South Carolina Department of Transportation (SCDOT), evaluated the USGS streamgage network in South Carolina in order to help guide decisions with respect to potential future streamgage location selections. The results of this evaluation are presented in this report. The supporting data for this report are available from Kolb and Feaster (2020).

\section{Purpose and Scope}

This report evaluates the USGS streamgage network in South Carolina, both spatially and in terms of the range of basin characteristics related to the regional flood-frequency equations that are currently available for South Carolina (Feaster and others, 2009, 2014). Therefore, this report focuses on streamgages that measure annual peak flows that are suitable for use in a regional flood-frequency regression analysis. An annual peak flow is defined as the largest instantaneous streamflow measurement at a USGS streamgage during the water year. The water year is the annual period from October 1 through September 30 and is designated by the year in which the period ends. The assessment includes streamgages that have at least one published peak flow through water year 2017 available in the USGS 


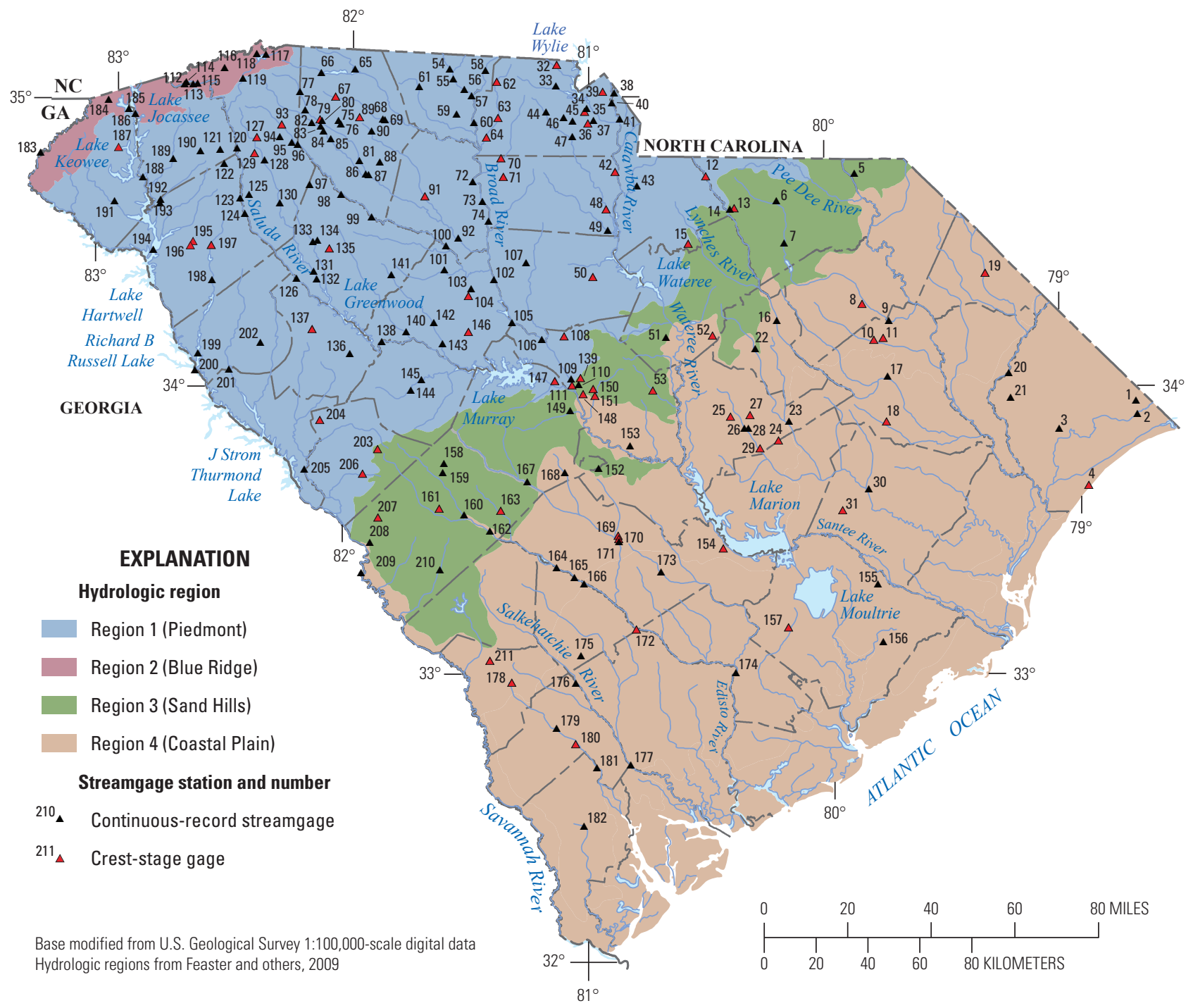

Figure 1. Map of hydrologic regions in South Carolina with the locations of streamgages that are included in this streamgage network assessment. 


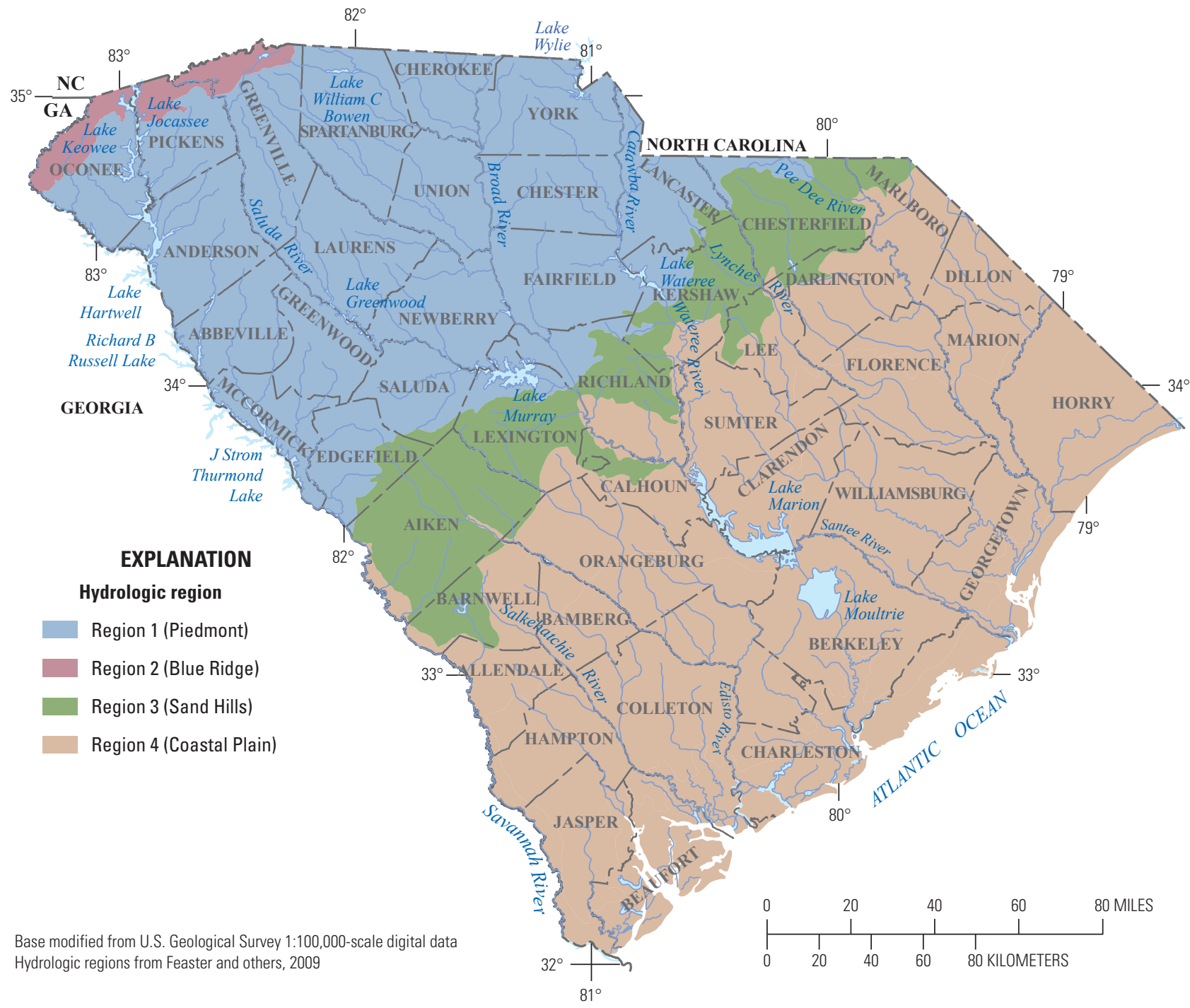

Figure 2. Map of counties and hydrologic regions in South Carolina. 
National Water Information System (NWIS) (fig. 1).

Streamgages that are substantially affected by tides or regulation or that monitor only stage (also referred to as water depth or gage height) are not suitable for a regional regression analysis; therefore, these streamgages were not included in this assessment. If flows at a streamgage were known to be regulated at low to medium flows but the regulation was insubstantial under high-flow conditions, the streamgage was included in the assessment.

The goal of this investigation was to assess the current and historical USGS streamgage network in South Carolina in order to reveal potential areas where future streamgage monitoring could be beneficial for flood-frequency analyses. Although the current rural and urban flood-frequency equations are applicable across Georgia, North Carolina, and South Carolina, the focus of this evaluation was on South Carolina. It does, however, include some basins that drain from surrounding States with an outlet point at a streamgage located in South Carolina.

\section{History of the Streamgage Network in South Carolina}

Around 1875, the Army Signal Corps began recording stream (or river) stage on the Savannah River near Augusta, Georgia (U.S. Geological Survey, 1958). The stage of a stream is defined here as the height or elevation of the water surface above an established datum (Sauer and Turnipseed, 2010). The earliest measurements of streamflow were made at the same location by the U.S. Army Corps of Engineers from 1884 to 1891. Using the Army Signal Corps stage records, the USGS computed streamflow for the period from 1884 to 1891. During this same timeframe, the U.S. Weather Bureau (currently the National Weather Service) also collected and published river stage information at this location (U.S. Geological Survey, 1958; Armbruster, 1970; Barker and others, 1985). In 1895, the USGS established about seven streamgages across North Carolina, South Carolina, and Virginia (U.S. Geological Survey, 1958). Growth of the streamgage network during that early period was slow, with the States of Georgia and North Carolina taking a leading interest in the program. Another streamgage was added in South Carolina in 1900 and the streamgage network remained the same until 1906. From 1906 through 1930, the number of streamgages varied from 0 (in 1910) to 14 (in 1930). During this period, streamgage records were maintained by the USGS office in Asheville, North Carolina.

On November 1, 1930, the USGS South Carolina District (now part of the USGS South Atlantic Water Science Center) was established as part of the USGS Water Resources Division. Cooperative programs began with the South Carolina State Highway Department (now the South Carolina Department of Transportation), several
Federal Power Commission licensees, and the U.S. Army Corps of Engineers. In 1934, three new streamgages were built through a cooperative agreement with the U.S. Soil Erosion Service (now the Natural Resources Conservation Service of the U.S. Department of Agriculture). At the request of the U.S. Army Corps of Engineers, six new streamgages were established in 1938. By 1939, the USGS South Carolina District was operating 54 streamgages, 33 of which had automatic recorders. By 1969, the South Carolina streamgage network had grown to 66 stations. The streamgaging program continued to grow, and by 1988 , the network included 102 continuous-record streamgages and 41 crest-stage gages (Bennett and others, 1989).

Before the late 1980s, the USGS collected hydrologic data in South Carolina by using digital-recorder tapes (Rantz, 1982). Every 15 minutes, the data collected at each site were mechanically punched into a continuous paper strip. The strip tape resembled a paper roll like that used in a cash register. A hydrologic technician collected the tape from each station about every 8 weeks during the field trip rotations. At the office, each tape was read by the "tape reader," a device that converted the mechanically punched hydrologic data to a digital format that could be viewed in the Automated Data Acquisition Processing System (ADAPS). Consequently, the data could be as much as 8 weeks old before it was available for use. If the streamgage equipment had a problem between the technician's field trips, it was not discovered until the technician returned to the site.

In the late 1980s, satellite telemetry was pioneered in the Charleston area of South Carolina as part of a gaging network to monitor saltwater intrusion (T.H. Lanier, U.S. Geological Survey, written commun., 2019). For the saltwater intrusion network to be effective, the data needed to be transmitted in real time or near real time. Because some locations on the Cooper River were remote, using telephone transmission was not an option. This situation prompted the USGS South Carolina District to establish a stand-alone ground station for satellite telemetry. Along with processing transmissions from South Carolina streamgages, the ground station processed data from 13 other States. By the mid-1990s, South Carolina had completely converted all streamgage-monitoring equipment to this new system and had discontinued using paper tapes at all stations.

\section{Methods}

Streamgages provide data for a variety of needs, including flood-plain management, flood insurance studies, and understanding and determining the magnitude and frequency of floods for the design of transportation and water-conveyance structures (Feaster and others, 2009). Streamflow data are also important to water-resource managers and engineers for planning and decision making related to agriculture, riverine and riparian habitats, and 
navigation (U.S. Geological Survey, 1999). In addition, low-flow characteristics are needed by State environmental managers for: determining waste-load allocations for point sources, developing total maximum daily loads for streams, determining the quantity of water that can be safely withdrawn from a particular stream, and preparing State water plans (Feaster and Guimaraes, 2017). Therefore, the locations of streamgages are often determined on the basis of the needs of a specific cooperator.

With respect to streamgage network design (or assessments of potential gaps in an existing network), many different approaches can be used. Some network design studies have been based on statistical techniques for the purpose of reducing uncertainty in streamflow-related estimates (National Research Council, 2004). Other network design approaches may focus on spatial coverage so that representative streamflow information is obtained throughout a region or subregion. A recent national streamflow network gap analysis incorporated spatial gap analysis, uncertainty analysis, and a temporal gap analysis to characterize changes in the network over time (Kiang and others, 2013).

The streamgage gap analysis for South Carolina presented in this report has a narrow focus, which is to assess the current and historical streamgages that could potentially be included in a regional flood-frequency study. This analysis focused on the areal coverage of the network, the range of the drainage areas of the stations, the range of percentages of impervious area for the basins considered to be substantially urban (for the purpose of this assessment, 10 percent or more), and the number of streamgages within each of the four South Carolina hydrologic regions as defined by Feaster and others $(2009,2014)$.

\section{Data Compilation}

This streamgage network assessment focuses on streamgages that measure annual peak-flow data that can be used in a flood-frequency investigation. In South Carolina, the USGS predominantly collects peak-flow data using either continuous-record (CR) streamgages or crest-stage gages (CSGs). The peak-flow data used in this report were obtained from the USGS NWIS database (U.S. Geological Survey, 2019). An initial dataset was compiled that included any South Carolina streamgage in the USGS NWIS that had at least one peak flow through September 30, 2017. Excluded from this initial set of data were streamgages that were known (or suspected) to be substantially affected by regulation or tides under high-flow conditions.
U.S. Geological Survey CR streamgages operate autonomously, collecting data at regular time intervals (such as every 15 minutes) depending on watershed size and how rapidly the water rises in the stream. Typical streamgage records include observations of stage. The stage data are collected using a variety of methods, including floats, submersible pressure transducers, nonsubmersible pressure transducers, or noncontact radar (Sauer and Turnipseed, 2010; Lurry, 2011).

Although stage data are important, streamflow is often more important for purposes such as streamflow forecasting and flood warning, water-quality loading computations, floodfrequency analysis, and flood mitigation planning. However, streamflow is not directly measured at streamgage locations. When a streamgage is established, the USGS computes stream discharge (also referred to here as "streamflow") over a range of stages, which involves measuring the velocity, stage, and area of the streamflow and then computing the discharge using those characteristics. Once a series of discharge computations have been made over a range of stages that reasonably characterize the streamflows that occur at a location, a relation between stage and discharge, or a rating curve, can be developed (Rantz, 1982; Lurry, 2011). The rating curve can then be used to convert the stage (or "gage height") data that is measured by the streamgage equipment into streamflow (fig. 3). However, after a rating curve is developed for a streamgage, USGS personnel continue to collect physical observations of velocity, stage, and area onsite at regular intervals (about every six weeks) (fig. 4) to determine near-instantaneous streamflow and to verify the accuracy of the rating curve.

When only the annual peak-flow data are needed at a location, those data can be more economically collected by using a CSG (Sauer and Turnipseed, 2010) (fig. 5). A typical CSG is constructed by using a vertical piece of 2-inch galvanized pipe with a bottom cap containing intake holes and a vent hole in a top cap. The bottom part of the pipe also contains a pin that is surveyed into a local datum. A long wooden, aluminum, or plastic stick is placed inside the pipe and sits on the pin. Shredded cork is placed in the bottom cap and, as the water rises and enters the pipe, bits of cork adhere to the stick and leave a mark at the water's highest level (Koenig and others, 2016). The peak stage is then measured from the stick by field personnel during the next site visit. The peak stage can be converted to a peak flow by using either a rating curve that has been developed for the site (as previously discussed) or by using a theoretical rating (such as a culvert rating) when site conditions are appropriate (Bodhaine, 1968; Bradley, 2013). 


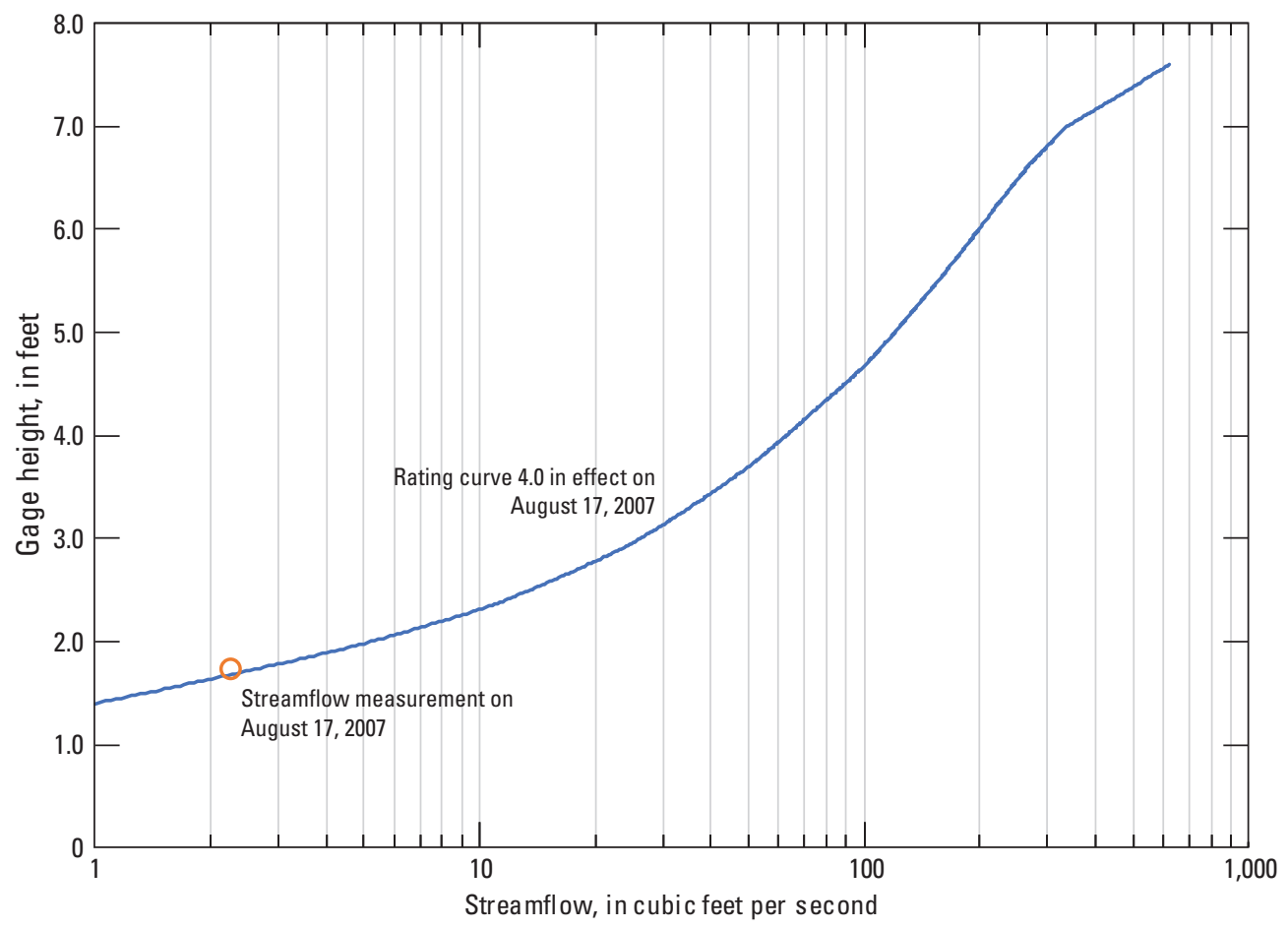

Figure 3. Graph showing rating curve 4.0 at station 02172300, McTier Creek near Moneta, South Carolina, August 17, 2007.

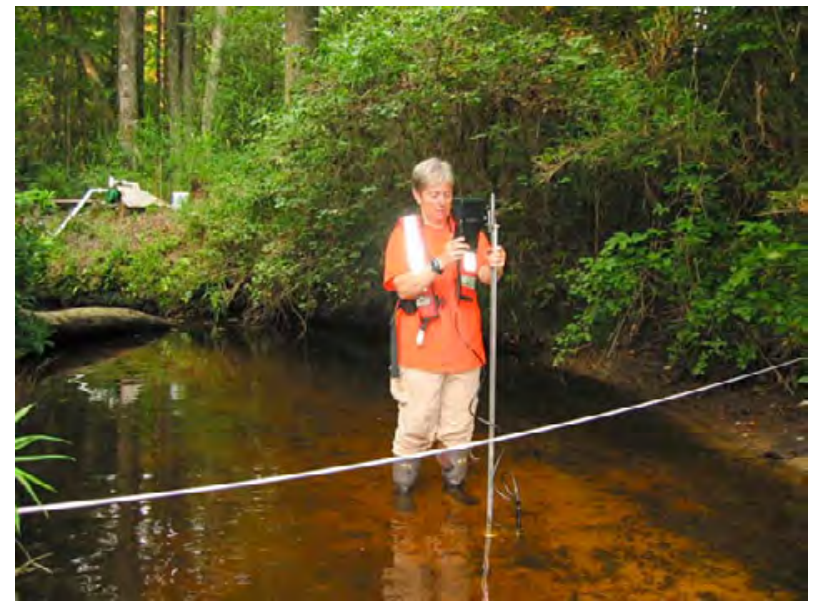

Figure 4. Photograph of a U.S. Geological Survey hydrologic technician taking a streamflow measurement near station 02172300, McTier Creek near Monetta, South Carolina, on August 17, 2007. Photograph by Toby D. Feaster, U.S. Geological Survey. 
$\boldsymbol{A}$

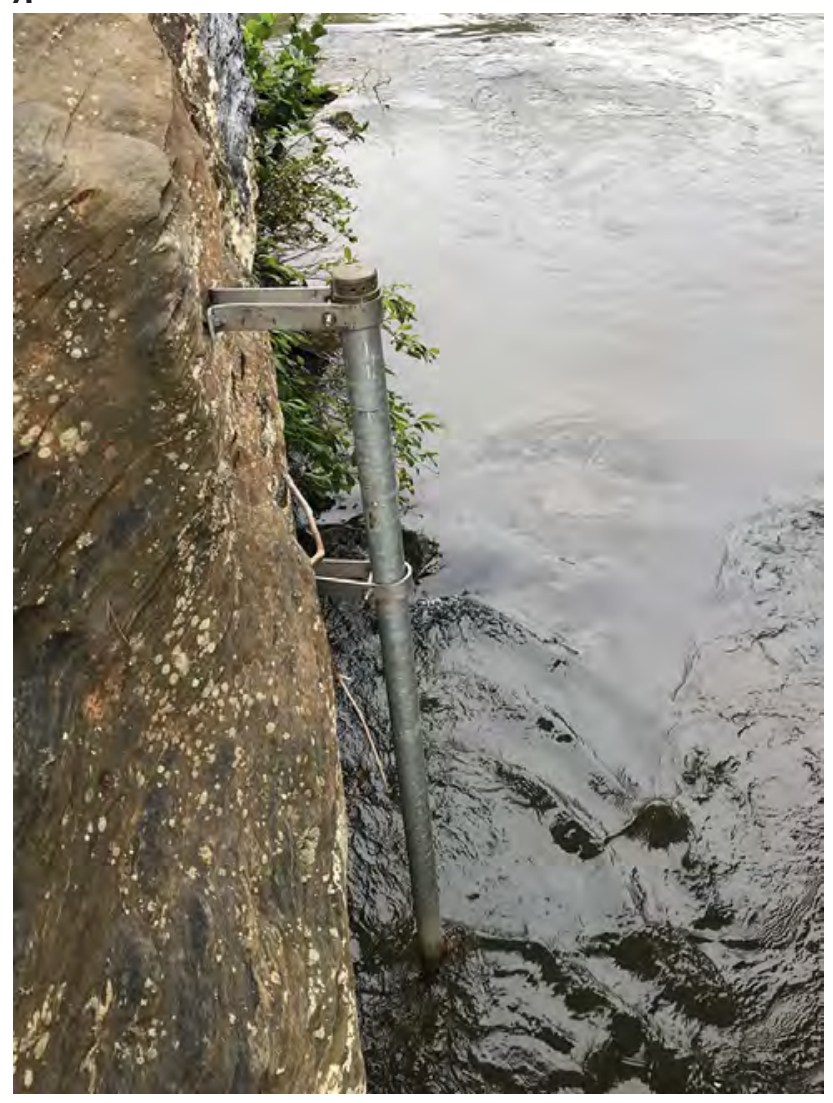

$\boldsymbol{B}$

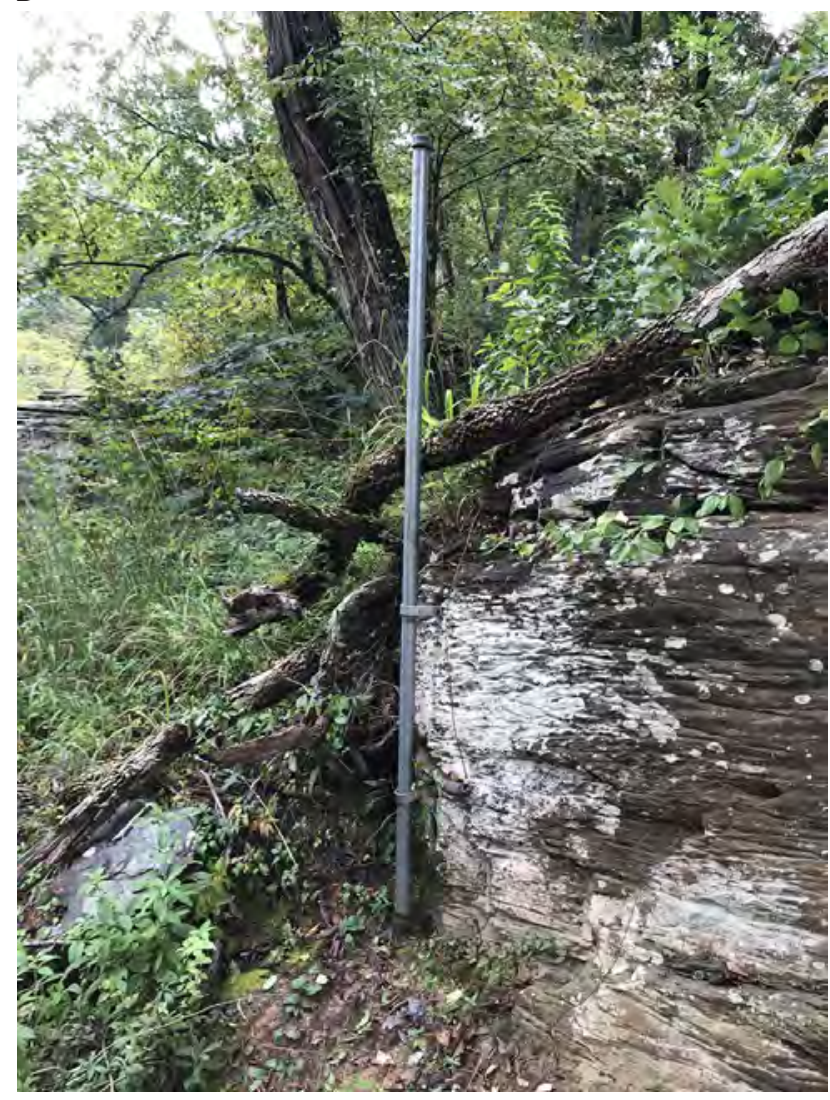

Figure 5. Photographs of crest-stage gages (CSGs) at U.S. Geological Survey station 02185200, Little River near Walhalla, South Carolina, on September 14, 2019, for (A) main-channel flow and (B) flood-plain flow. Photographs by Toby D. Feaster, U.S. Geological Survey.

\section{Basin Characteristics}

Geographic information system (GIS) tools were utilized to map the location of current and historical rural and urban streamgages that are differentiated by length of record. Additionally, the drainage basin was delineated for each streamgage to analyze the spatial coverage of the streamgage network (pl. 1). Sites were grouped into three categories for this analysis: rural streamgages with 10 or more years of record, rural streamgages with less than 10 years of record, and urban streamgages (apps. 1, 2, and 3). Streamgages were additionally categorized as CR streamgages or CSGs and whether they were active or inactive as of September 30, 2017. Streamgages that were greatly affected by upstream regulation or tides during high-flow conditions were not included.

Drainage-basin boundaries were delineated by using the GIS layers in the USGS StreamStats application (https://streamstats.usgs.gov/ss/). The underlying data for the South Carolina StreamStats layers are described in Feaster and others (2018a). Streamgage locations were interactively snapped to the nearest stream location before delineation to ensure that the delineation points captured the full watershed. Drainage areas were compared with published values in NWIS for quality assurance. If the differences between the NWIS and StreamStats drainage areas were more than 2 percent, the basin delineations were reviewed. If it was concluded that the StreamStats values were more accurate, the NWIS drainage areas were updated to the value computed using StreamStats.

Along with drainage area, two additional basin characteristics were calculated for each basin by using GIS geoprocessing: percent of impervious area and percent of the basin in each hydrologic region (apps. 1, 2, and 3). The amount of impervious surface in a watershed affects the runoff, especially in urban watersheds where that percentage is commonly greater compared to rural watersheds; therefore, it is an important characteristic for flood-frequency analyses in urban basins. The percent of impervious area was calculated for each basin using the "Landcover" and "Imperviousness" layers in the National Land Cover Database 2016 (NLCD2016), as described by Yang and others (2018). The percent of the basin in each hydrologic region provides information on the spatial location of the basins as well as a means of quantifying the peak-flow contributions of each hydrologic region for basins that span multiply regions. The hydrologic regions for South Carolina, principally coincident with the Level III and Level IV ecoregions from Omernik (1987), are depicted in Feaster and others $(2009,2014)$. 


\section{Summary Statistics}

The streamgage network assessment was based on historical and current streamgages in the USGS South Carolina network as of September 30, 2017. This assessment yielded 211 streamgages that fit our requirements; these were then categorized into rural and urban stations and then into active and inactive stations (pl. 1). The rural streamgages were further divided into stations with 10 or more years of record (which is typically the minimum record length used in a flood-frequency analysis) and stations with less than 10 years of record. To compare the number of stations contained in each hydrologic region, this study also determined the number of stations for which at least 75 percent or more of the total drainage area was contained within a single hydrologic region.

\section{Rural Streamgages With 10 or More Years of Record}

For this assessment, the USGS streamgage network in South Carolina included 79 active rural streamgages with 10 or more years of record (app. 1). Of those streamgages, 48 were $\mathrm{CR}$ streamgages and 31 were CSGs. The drainage areas of these stations ranged from 0.53 square miles $\left(\mathrm{mi}^{2}\right)$ to $7,332 \mathrm{mi}^{2}$, with a mean of $522 \mathrm{mi}^{2}$ and a median of $94.7 \mathrm{mi}^{2}$ (fig. 6). The large differences between the mean and median drainage areas indicate that the areas of the basins being monitored are not normally distributed. As shown by the median value, 50 percent of the stations have drainage areas less than or equal to $94.7 \mathrm{mi}^{2}$. The 90th, 75th, 25th, and 10th percentiles for drainage area were $1,325,537,24.5$, and $5.79 \mathrm{mi}^{2}$, respectively. Thus, for example, 90 percent of the stations had drainage basin areas less than or equal to $1,325 \mathrm{mi}^{2}$. The percent of impervious area for the active rural stations ranged from 0.2 to 8.6 percent, with a mean of 2.0 percent and a median of 1.5 percent. The 90th and 75 th percentiles for percent of impervious area were 5.1 and 2.6 percent, respectively. Of the 79 active CR and CSG stations with 10 or more years of record, the number of streamgages across the four hydrologic regions for which 75 percent or more of the basin is contained within one hydrologic region is as follows: HR1-Piedmont, 38; HR2-Blue Ridge, 2; HR3-Sand Hills, 10; and HR4-Coastal Plain, 13 (table 1).

There were 42 inactive rural streamgages ( $34 \mathrm{CR}$ and 8 CSG) with 10 or more years of record (app. 1). The drainage areas of these stations ranged from 1.19 to $4,825 \mathrm{mi}^{2}$, with a mean of $360 \mathrm{mi}^{2}$ and a median of $57.7 \mathrm{mi}^{2}$ (fig. 6). The 90th percentile for drainage area was $964 \mathrm{mi}^{2}$. The percent of impervious area for the inactive streamgages ranged from 0.2 to 9.0 percent, with a mean of 2.5 and a median of 1.2 percent. Of the 42 inactive CR and CSG stations with 10 or more years of record, the number of streamgages across the four hydrologic regions for which 75 percent or more of the basin is contained within one hydrologic region is as follows: HR1-Piedmont, 20; HR2-Blue Ridge, 2; HR3-Sand Hills, 6; and HR4-Coastal Plain, 10 (table 1).

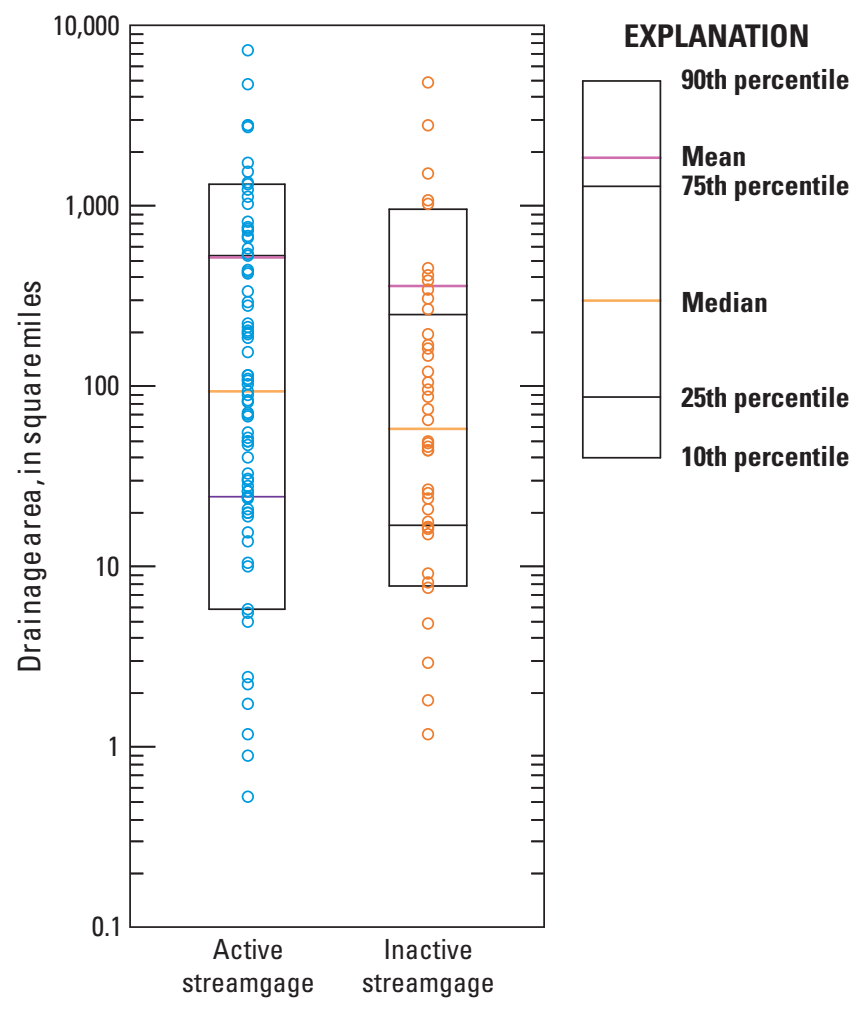

Figure 6. Box plot of drainage area for active and inactive rural streamgages in the U.S. Geological Survey streamgage network in South Carolina with 10 or more years of record along with the mean, median, and 90th, 75th, 25th, and 10th-percentile drainage areas. Each circle represents the drainage area for an individual streamgage. 
Table 1. Number of active and inactive streamgages across the four hydrologic regions (HRs) in South Carolina (Piedmont, Blue Ridge, Sand Hills, and Coastal Plain) for which 75 percent or more of the corresponding drainage basin is contained within one hydrologic region.

\begin{tabular}{|c|c|c|c|c|}
\hline Streamgage type & Piedmont (HR1) & Blue Ridge (HR2) & Sand Hills (HR3) & Coastal Plain (HR4) \\
\hline \multicolumn{5}{|c|}{ Rural streamgages with 10 or more years of record } \\
\hline Active & 38 & 2 & 10 & 13 \\
\hline Inactive & 20 & 2 & 6 & 10 \\
\hline \multicolumn{5}{|c|}{ Rural streamgages with less than 10 years of record } \\
\hline Active & 8 & 7 & 3 & 1 \\
\hline Inactive & 11 & 1 & 2 & 6 \\
\hline \multicolumn{5}{|c|}{ Urban streamgages } \\
\hline Active & 19 & 0 & 4 & 5 \\
\hline Inactive & 17 & 0 & 1 & 3 \\
\hline
\end{tabular}

\section{Rural Streamgages With Less Than 10 Years of Record}

For the rural streamgages with less than 10 years of record, there were 19 active streamgages (app. 2). Of those, 17 were CR streamgages and 2 were CSGs. The drainage areas of these stations ranged from 2.21 to $5,230 \mathrm{mi}^{2}$, with a mean of $463 \mathrm{mi}^{2}$ and a median of $17.8 \mathrm{mi}^{2}$ (fig. 7). The 90th and 75th percentiles for drainage area were 868 and $47.0 \mathrm{mi}^{2}$, respectively. The percent of impervious area for the active streamgages ranged from 0.0 to 6.9 percent, with a mean of 1.9 and a median of 1.2 percent. Of the 19 active CR and CSG stations with less than 10 years of record, the number of streamgages across the four hydrologic regions for which 75 percent or more of the basin is contained within one hydrologic region is as follows: HR1-Piedmont, 8; HR2-Blue Ridge, 7; HR3-Sand Hills, 3; and HR4-Coastal Plain, 1 (table 1).

There were 22 inactive rural streamgages ( $20 \mathrm{CR}$ and 2 CSG) with less than 10 years of record (app. 2). The drainage areas of these stations ranged from 1.52 to $5,309 \mathrm{mi}^{2}$, with a mean of $777 \mathrm{mi}^{2}$ and a median of $72.3 \mathrm{mi}^{2}$ (fig. 7). The 90th and 75th percentiles for drainage area were 2,571 and $336 \mathrm{mi}^{2}$, respectively. The percent of impervious area ranged from 0.1 to 6.3 percent, with a mean of 2.7 and a median of 2.1 percent. Of the 22 active CR and CSG stations with less than 10 years of record, the number of streamgages across the four hydrologic regions for which 75 percent or more of the basin is contained within one hydrologic region is as follows: HR1-Piedmont, 11; HR2-Blue Ridge, 1; HR3-Sand Hills, 2; and HR4-Coastal Plain, 6 (table 1).

\section{Urban Streamgages}

For the urban streamgages, there were 28 active stations (15 CR and 13 CSG) (app. 3). Because all the active urban streamgages have 10 or more years of peak-flow record, they were not separated by years of record as was done for the rural streamgages. The drainage areas of these stations ranged from 0.27 to $264 \mathrm{mi}^{2}$, with a mean of $48.7 \mathrm{mi}^{2}$ and a median of $7.94 \mathrm{mi}^{2}$ (fig. 8). The 90th and 75th percentiles for drainage area were 152 and $62.9 \mathrm{mi}^{2}$, respectively. The percent of impervious area ranged from 10.4 to 43.9 percent, with a mean of 23.3 and a median of 24.4 percent. Of the 28 active $\mathrm{CR}$ and CSG stations, the number of streamgages across the four hydrologic regions for which 75 percent or more of the basin is contained within one hydrologic region is as follows: HR1-Piedmont, 19; HR2-Blue Ridge, 0; HR3-Sand Hills, 4; and HR4-Coastal Plain, 5 (table 1).

The assessment included 21 inactive urban streamgages (13 CR and $8 \mathrm{CSG})$. The drainage areas of these stations ranged from 0.70 to $275 \mathrm{mi}^{2}$, with a mean of $33.1 \mathrm{mi}^{2}$ and a median of $3.41 \mathrm{mi}^{2}$ (fig. 8). The 90th and 75th percentiles for the drainage area were 76.0 and $14.2 \mathrm{mi}^{2}$, respectively. The percent of impervious area ranged from 10.2 to 48.9 percent, with a mean of 21.7 and a median of 18.5 percent. Of the 21 inactive CR and CSG stations, the number of streamgages across the four hydrologic regions for which 75 percent or more of the basin is contained within one hydrologic region is as follows: HR1-Piedmont, 17; HR2-Blue Ridge, 0; HR3-Sand Hills, 1; and HR4-Coastal Plain, 3 (table 1). 


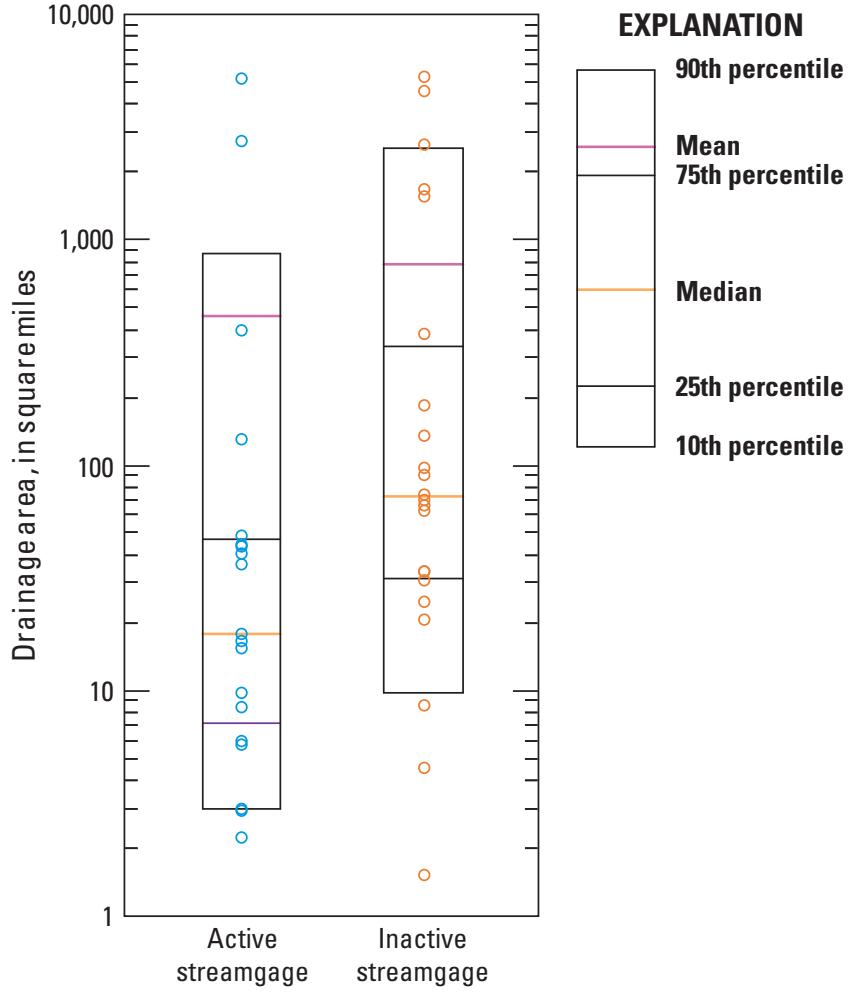

Figure 7. Box plot of drainage area for active and inactive rural streamgages in the U.S. Geological Survey streamgage network in South Carolina with less than 10 years of record along with the mean, median, and 90th, 75th, 25th, and 10th-percentile drainage areas. Each circle represents the drainage area for an individual streamgage.

\section{Considerations for the Selection of New Streamgage Locations}

The goal of this report was to analyze the historical and current USGS streamgage network in South Carolina to identify potential areas where future streamgage monitoring could be beneficial for flood-frequency analyses. The current rural and urban flood-frequency equations for South Carolina include four hydrologic regions (figs. 1, 2), as described by Feaster and others $(2009,2014)$. At streamgage locations, flood-frequency analyses are strongly affected by length of record and the hydrologic conditions that are captured in that record. Typically, longer streamflow records will capture a broader range of hydrologic conditions. The flood-frequency statistics from those streamgages can then be included in a regional regression analysis to develop flood-frequency equations, which can then be used to generate flood-frequency estimates at ungaged locations (Farmer and others, 2019). Therefore, the goal of a streamgage network established for the purpose of developing flood-frequency estimates is to provide good spatial coverage of each hydrologic region and, in doing so, also capture a wide range of the basin characteristics that

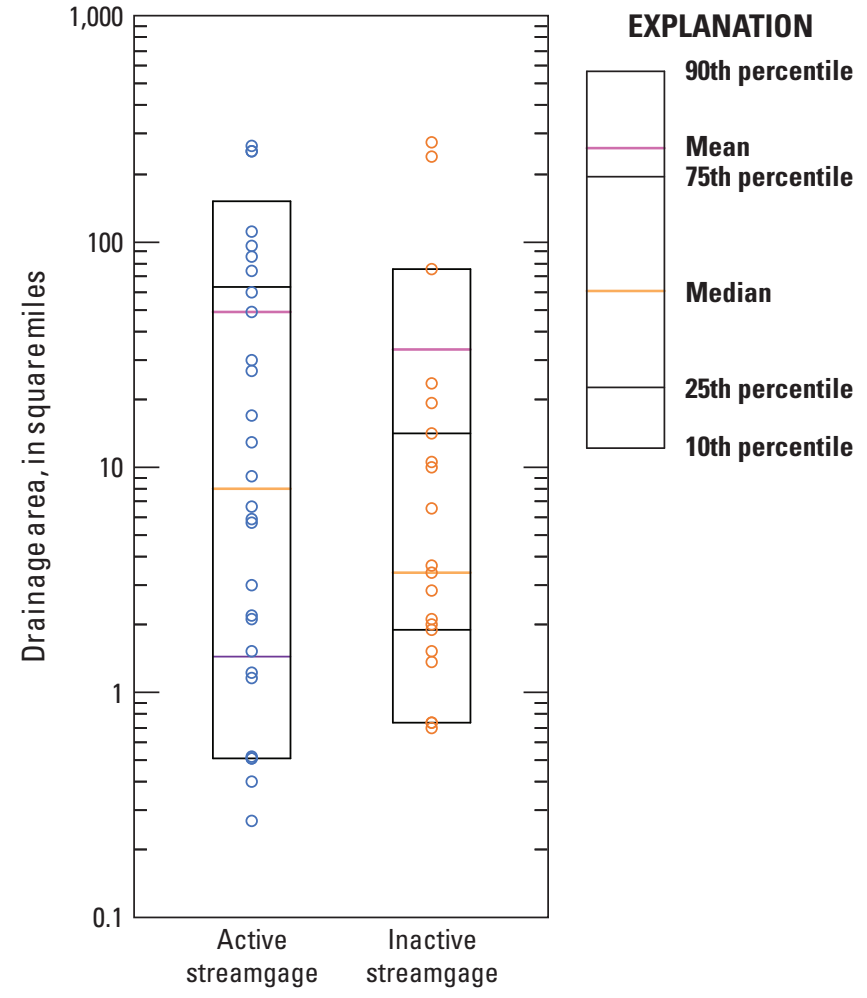

Figure 8. Box plot of drainage area for active and inactive urban streamgages in the U.S. Geological Survey streamgage network in South Carolina along with the mean, median, and 90th, 75th, 25th, and 10th-percentile drainage areas. Each circle represents the drainage area for an individual streamgage.

are relevant to the regional flood-frequency equations. Below are a few considerations on how the information provided in this report can be used to help select streamgage locations to attain these goals.

1. Review the information in table 1 and on plate 1 to assess potential regions and geographical locations where new streamgages might be useful.

2. Review the information in appendixes 1,2 , and 3 to determine whether there is an inactive streamgage in the region of interest that might be suitable for reactivation. It may also be helpful to discuss the history of the inactive streamgage with appropriate personnel in the USGS South Carolina Water Science Center. Streamgages may become inactive as a result of changes in funding or because the operation of a streamgage at the location is no longer considered practical or useful.

3. If there are no suitable inactive streamgages in the hydrologic region of interest, review plate 1 and the drainage-area information in appendixes 1,2, and 3 to determine a range of desirable drainage-area sizes for the hydrologic region of interest. 
4. Utilize the South Carolina StreamStats application (https://streamstats.usgs.gov/ss/) to select candidate bridge crossings along streams of interest. Generate the drainage area and impervious area to determine whether the candidate location has suitable basin characteristics.

5. For urban basins, it is desirable to establish streamgages at locations in which the urbanization is likely to remain relatively stable and, therefore, the annual peak flows will be more likely to represent a consistent hydrologic condition.

6. If the drainage area of a potential ungaged location is within 0.5 to 1.5 times the drainage-area size of a current or historical streamgage, it may be suitable to transfer flood-frequency information from that streamgage to the location where the potential new streamgage is being considered. Thus, installing a new streamgage at that location would not be practical because it would result in a nested condition in which the flood-frequency information from the two locations would be considered redundant.

\section{Summary}

The historical and current (as of September 30, 2017) U.S. Geological Survey streamgage network in South Carolina was assessed in terms of areal coverage throughout the State and in terms of basin characteristics that are important factors in flood-frequency regionalization equations. For the areal coverage, a map was generated to show the streamgage locations along with their respective drainage basins (pl. 1). The streamgages were categorized into three groups: rural streamgages with 10 or more years of record, rural streamgages with less than 10 years of record, and urban streamgages. The streamgages were further categorized as active or inactive and continuous-record (CR) or crest-stage gage (CSG) stations. The total number of stations included in the assessment was 211.

For the rural streamgages with 10 or more years of record, there were 79 active stations and 42 inactive stations. Of the 79 active stations, 48 were CR streamgages and 31 were CSGs. The drainage areas ranged from 0.53 square miles $\left(\mathrm{mi}^{2}\right)$ to $7,332 \mathrm{mi}^{2}$, with a mean drainage area of $522 \mathrm{mi}^{2}$ and a median of $94.7 \mathrm{mi}^{2}$. For the 42 inactive stations, there were $34 \mathrm{CR}$ streamgages and 8 CSGs with drainage areas that ranged from 1.19 to $4,825 \mathrm{mi}^{2}$. The mean drainage area for these stations was $360 \mathrm{mi}^{2}$ and the median was $57.7 \mathrm{mi}^{2}$.

For the rural streamgages with less than 10 years of record, there were 19 active stations, 17 of which were CR streamgages and 2 of which were CSGs. The drainage areas of these stations ranged from 2.21 to $5,230 \mathrm{mi}^{2}$, with a mean of $463 \mathrm{mi}^{2}$ and a median of $17.8 \mathrm{mi}^{2}$. There were 22 inactive streamgages with less than 10 years of record, with 20 being CR stations and 2 being CSGs. These drainage areas ranged from 1.52 to $5,309 \mathrm{mi}^{2}$, with a mean of $777 \mathrm{mi}^{2}$ and a median of $72.3 \mathrm{mi}^{2}$.
For the urban streamgages (all whose drainage basins had impervious areas of 10 percent or more), there were 28 active stations, 15 of which were CR streamgages and 13 of which were CSGs. The drainage areas of these stations ranged from 0.27 to $264 \mathrm{mi}^{2}$, with a mean of $48.7 \mathrm{mi}^{2}$ and a median of $7.94 \mathrm{mi}^{2}$. The percent of impervious area for these stations ranged from 10.4 to 43.9 percent, with a mean of 23.3 and a median of 24.4 percent.

This assessment also included 21 inactive urban streamgages, 13 of which were CR streamgages and 8 of which were CSGs. The drainage areas of these stations ranged from 0.70 to $275 \mathrm{mi}^{2}$, with a mean of $33.1 \mathrm{mi}^{2}$ and a median of $3.41 \mathrm{mi}^{2}$. The percent of impervious area for the inactive stations ranged from 10.2 to 48.9 percent, with a mean of 21.7 and a median of 18.5 percent.

\section{References Cited}

Armbruster, J.T., 1970, A proposed streamflow data program for South Carolina: U.S. Geological Survey Open-File Report 70-11, 30 p. [Also available at https://doi.org/ 10.3133/ofr7011.]

Barker, A.C., Wright, B.C., and Bennett, C.S., III, 1985, Cost effectiveness of the stream-gaging program in South Carolina: U.S. Geological Survey Water-Resources Investigations Report 85-4210, 83 p. [Also available at https://pubs.er.usgs.gov/publication/wri854210.]

Bennett, C.S., Hayes, R.D., Jones, K.H., and Cooney, T.W., 1989, Water resources data, water year 1988: U.S. Geological Survey Water-Data Report SC-88-1, 598 p.

Bodhaine, G.L., 1968, Measurement of peak discharge at culverts by indirect methods: U.S. Geological Survey Techniques of Water-Resources Investigations, book 3 , chap. A3, $60 \mathrm{p}$.

Bradley, D.N., 2013, Culvert analysis program graphical user interface 1.0-A preprocessing and postprocessing tool for estimating flow through culverts: U.S. Geological Survey Fact Sheet 2013-3045, 4 p. [Also available at https://doi.org/10.3133/fs20133045.]

Farmer, W.H., Kiang, J.E., Feaster, T.D., and Eng, K., 2019, Regionalization of surface-water statistics using multiple linear regression: U.S. Geological Survey Techniques and Methods, book 4, chap. A12, 40 p. [Also available at https://doi.org/10.3133/tm4A12.]

Feaster, T.D., Clark, J.M., and Kolb, K.R., 2018a, StreamStats for South Carolina-A multipurpose water-resources web application: U.S. Geological Survey Fact Sheet 2018-3070, 5 p. [Also available at https://doi.org/10.3133/fs20183070.] 
Feaster, T.D., Gotvald, A.J., and Weaver, J.C., 2009, Magnitude and frequency of rural floods in the southeastern United States, 2006-Volume 3, South Carolina: U.S. Geological Survey Scientific Investigations Report 2009-5156, 226 p. [Also available at https://doi.org/ 10.3133/sir20095156.]

Feaster, T.D., Gotvald, A.J., and Weaver, J.C., 2014, Methods for estimating the magnitude and frequency of floods for urban and small, rural streams in Georgia, South Carolina, and North Carolina, 2011 (ver. 1.1, March 2014): U.S. Geological Survey Scientific Investigations Report 2014-5030, 104 p. [Also available at https://dx.doi.org/ 10.3133/sir20145030.]

Feaster, T.D., and Guimaraes, W.B., 2017, Low-flow characteristics of streams in South Carolina: U.S. Geological Survey Open-File Report 2017-1110, 161 p. [Also available at https://doi.org/10.3133/ofr20171110.]

Feaster, T.D., Shelton, J.M., and Robbins, J.C., 2015, Preliminary peak stage and streamflow data at selected USGS streamgaging stations for the South Carolina flood of October 2015 (ver. 1.1, November 2015): U.S. Geological Survey Open-File Report 2015-1201, 19 p. [Also available at https://dx.doi.org/10.3133/ofr20151201.]

Feaster, T.D., Weaver, J.C., Gotvald, A.J., and Kolb, K.R., 2018 b, Preliminary peak stage and streamflow data at selected U.S. Geological Survey streamgaging stations in North and South Carolina for flooding following Hurricane Florence, September 2018: U.S. Geological Survey Open-File Report 2018-1172, 36 p. [Also available at https://doi.org/10.3133/ofr20181172.]

Kiang, J.E., Stewart, D.W., Archfield, S.A., Osborne, E.B., and Eng, K., 2013, A national streamflow network gap analysis: U.S. Geological Survey Scientific Investigations Report 2013-5013, 79 p., 1 app. [Also available at https://pubs.usgs.gov/sir/2013/5013/.]

Koenig, T.A., Bruce, J.L., O’Connor, J.E., McGee, B.D., Holmes, R.R., Jr., Hollins, R., Forbes, B.T., Kohn, M.S., Schellekens, M.F., Martin, Z.W., and Peppler, M.C., 2016, Identifying and preserving high-water mark data: U.S. Geological Survey Techniques and Methods, book 3, chap. A24, 47 p. [Also available at https://doi.org/10.3133/ tm3A24.]

Kolb, K.R., and Feaster, T.D., 2020, Data for the evaluation of the U.S. Geological Survey streamgage network in South Carolina, 2017: U.S. Geological Survey data release. [Also available at https://doi.org/10.5066/P9X5F4B1.]

Lurry, D.L., 2011, How does a U.S. Geological Survey streamgage work?: U.S. Geological Survey Fact Sheet 2011-3001, 2 p. [Also available at https://doi.org/10.3133/ fs20113001.]
National Research Council, 2004, Assessing the National Streamflow Information Program-National Research Council of the National Academies, Committee on Review of the USGS National Streamflow Information Program, Water Science and Technology Board, Division on Earth and Life Studies: Washington, D.C., The National Academies Press, $176 \mathrm{p}$.

Omernik, J.M., 1987, Ecoregions of the conterminous United States: Annals of the Association of American Geographers, v. 77, no. 1, p. 118-125, scale 1:7,500,000.

Rantz, S.E., 1982, Measurement and computation of streamflow-Volume 2, Computation of discharge: U.S. Geological Survey Water-Supply Paper 2175, 376 p. [Also available at https://pubs.er.usgs.gov/publication/ wsp2175.]

Sauer, V.B., and Turnipseed, D.P., 2010, Stage measurement at gaging stations: U.S. Geological Survey Techniques and Methods, book 3, chap. A7, 45 p. [Also available at https://pubs.usgs.gov/tm/tm3-a7/.]

U.S. Geological Survey, 1958, Compilation of records of surface waters of the United States through September 1950, Part 2-A, South Atlantic slope basins, James River to Savannah River: U.S. Geological Survey Water-Supply Paper 1303, 325 p. [Also available at https://pubs.er.usgs.gov/publication/wsp1303.]

U.S. Geological Survey, 1999, Streamflow information for the next century-A plan for the National Streamflow Information Program of the U.S. Geological Survey: U.S. Geological Survey Open-File Report 99-456, 18 p.

U.S. Geological Survey, 2019, USGS water data for the Nation: U.S. Geological Survey National Water Information System database, accessed February 21, 2019, at https://doi.org/10.5066/F7P55KJN.

Weaver, J.C., Feaster, T.D., and Robbins, J.C., 2016, Preliminary peak stage and streamflow data at selected streamgaging stations in North Carolina and South Carolina for flooding following Hurricane Matthew, October 2016: U.S. Geological Survey Open-File Report 2016-1205, 38 p. [Also available at https://doi.org/10.3133/ofr20161205.]

Yang, L., Jin, S., Danielson, P., Homer, C., Gass, L., Bender, S.M., Case, A., Costello, C., Dewitz, J., Fry, J., Funk, M., Granneman, B., Liknes, G.C., Rigge, M., and Xian, G., 2018, A new generation of the United States National Land Cover Database-Requirements, research priorities, design, and implementation strategies: ISPRS Journal of Photogrammetry and Remote Sensing, v. 146, p. 108-123. [Also available at https://doi.org/10.1016/ j.isprsjprs.2018.09.006.] 


\section{Appendix 1. U.S. Geological Survey Streamgages in South Carolina With Record Through September 2017-Rural Streamgages With 10 or More Years of Record}

Table 1.1 of appendix 1 lists the U.S. Geological Survey rural streamgages with 10 or more years of record in South Carolina through September 2017 that were included in the streamgage network assessment.

Abbreviations used in table 1.1 are as follows: CR, continuous-record streamgage; $\mathrm{CSG}$, crest-stage gage;

DA, drainage area; GA, Georgia; HR, hydrologic region;
HUC, hydrologic unit code; mi², square mile; NLCD 2016, National Land Cover Database 2016; NWIS, National Water Information System; SC, South Carolina; xx, month and (or) day unknown.

Table 1.1 is available as a separate Microsoft Excel file at https://doi.org/10.3133/ofr20201104. 


\section{Appendix 2. U.S. Geological Survey Streamgages in South Carolina With Record Through September 2017-Rural Streamgages With Less Than 10 Years of Record}

Table 2.1 of appendix 2 lists the U.S. Geological Survey rural streamgages with less than 10 years of record in South Carolina through September 2017 that were included in the streamgage network assessment.

Abbreviations used in table 2.1 are as follows: CR, continuous-record streamgage; CSG, crest-stage gage; DA, drainage area; HR, hydrologic region; HUC, hydrologic unit code; $\mathrm{mi}^{2}$, square mile; NLCD 2016, National Land Cover Database 2016; NWIS, National Water Information System; SC, South Carolina; xx, month and (or) day unknown.

Table 2.1 is available as a separate Microsoft Excel file at https://doi.org/10.3133/ofr20201104. 


\section{Appendix 3. U.S. Geological Survey Streamgages in South Carolina With Record Through September 2017—Urban Streamgages With Varying Years of Record}

Table 3.1 of appendix 3 lists the U.S. Geological Survey urban streamgages with varying years of record in South Carolina through September 2017 that were included in the streamgage network assessment.

Abbreviations used in table 3.1 are as follows: CR, continuous-record streamgage; CSG, crest-stage gage; DA, drainage area; HR, hydrologic region; HUC, hydrologic unit code; $\mathrm{mi}^{2}$, square mile; NLCD 2016, National Land Cover Database 2016; NWIS, National Water Information System; SC, South Carolina.

Table 3.1 is available as a separate Microsoft Excel file at https://doi.org/10.3133/ofr20201104. 

Manuscript approved on September 4, 2020

For additional information, contact:

Director, South Atlantic Water Science Center

U.S. Geological Survey

1770 Corporate Drive

Suite 500

Norcross, GA 30093

For additional information visit https://www.usgs.gov/centers/sa-water

Publishing support provided by the Reston Publishing Service Center 


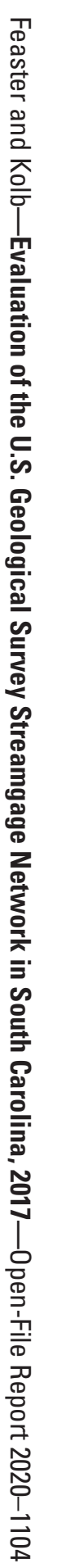

